\title{
In situ application of high and ultra high strength concrete
} MSc Civil Engineer, PhD student at BME, Department of Construction Materials and Technologies. Fields of interest: porosity of concrete, self compacting concretes, high performance concretes.

Abdulkader EL MIR - BME Department of Construction Materials and Technologies - abdelkader.elmir@hotmail.com

Salem Georges NEHME - ME Department of Construction Materials and Technologies - sgnehme@yahoo.com

KINGA NEHME - University of Debrecen, Department of Civil Engineering - kpankhardt@yahoo.com Érkezett: 2015. 12. 10. - Received: 10. 12. 2015. - http://dx.doi.org/10.14382/epitoanyag-jsbcm.2016.4

\section{Abstract}

High strength concrete (HSC) and ultra-high strength concrete (UHSC) have become today highly required due to their enhanced properties in terms of strength and durability. An experimental program was executed at BME, Department of Construction Materials and Technologies in order to evaluate the mechanical properties of HSC and UHSC mixtures including supplementary cementitious materials (SCM) such as silica fume and metakaolin, to achieve the optimal mixture for site applications. Compressive strength was evaluated at different ages. Variable parameters were the amount of water, cement and SCM. Several alterations were performed to reach the required strength by the designers. Based on the laboratory experiment results, the most effective replacement amount of cement is $8 \%$ for SF and $17 \%$ for MK.

Keywords: compressive strength, high strength concrete, optimization, ultra-high strength concrete.

\section{Introduction}

The concept of high-strength concrete (HSC) has been varied and manipulated over time. Since 1950, concrete with $34 \mathrm{MPa}$ compressive strength was considered HSC. With the progress of time and technology, HSC compressive strength today reaching $140 \mathrm{MPa}$ was applied to be cast-in-place. Also laboratory researches were able to reach $800 \mathrm{MPa}$ compressive strength using special type of materials [1]. Hence the definition of HSC is by no means static. High performance concrete (HPC) is the recent terminology which is defined based on obtaining high strength and durable concrete simultaneously. It is basically constituted of the same materials of normal concrete where supplementary cementitious materials (SCM) and admixtures are added to obtain the required properties. Several mega structures were completed applying this technology. For instance Tapei 101 located in Taiwan and Burj Khalifa in United Arab Emirates were built under this technology. Based on the recommendation of ACI 363 Committee, we can define that HSC to be high strength where the material in range of 40 to $55 \mathrm{MPa}$ at the ages of 28 days or later [2]. Nowadays, due to the developing of the chemical industry and application of advanced additive materials, ultra-high-performance concrete (UHPC) or ultra-high-strength (UHSC) with compressive strength ranging about 100-200 MPa can be reached, as well. It is produced using binding materials and very fine powders such as cement, silica fume, crushed quartz and metakaolin [3-6]. It is characterized by its dense microstructure and very low porosity in which is limited to $9 \%$ in volume on the pre diameter ranged between $3.75 \mathrm{~nm}$ to $100 \mu \mathrm{m}$ [7].

Porosity and compressive strength of concrete are interconnected and directly influence the failure behavior of the material. Void spaces with variety of sizes and micro cracks in the concrete matrix define the complex failure mode which varies with the type of stress applied. It is agreed that, medium or low strength concrete under uniaxial loading, no cracks are induced in the matrix up to about 50 percent of stress failure whereas at this level a stable state of cracks, known as shearbond cracks, already exists in the vicinity of coarse aggregate. At higher stress levels, cracks are initiated within the matrix; their number and size increases progressively with increasing stress levels. Also, initial cracks in the matrix and the interfacial transition zone (shear-bond cracks) eventually meet up to the final failure mode.

According to Fig. 1, failure mode of concrete cubes tends to change depending on porosity.

The relationship between strength and cement content is not directly proportional as the one between water to cement ratio $(w / c)$ and strength [8-13].

Not only the cement influences the failure behavior, the aggregate to cement ratio has an effect on the strength, as well: mainly the type of aggregates and it can be noticed in high strength concrete.

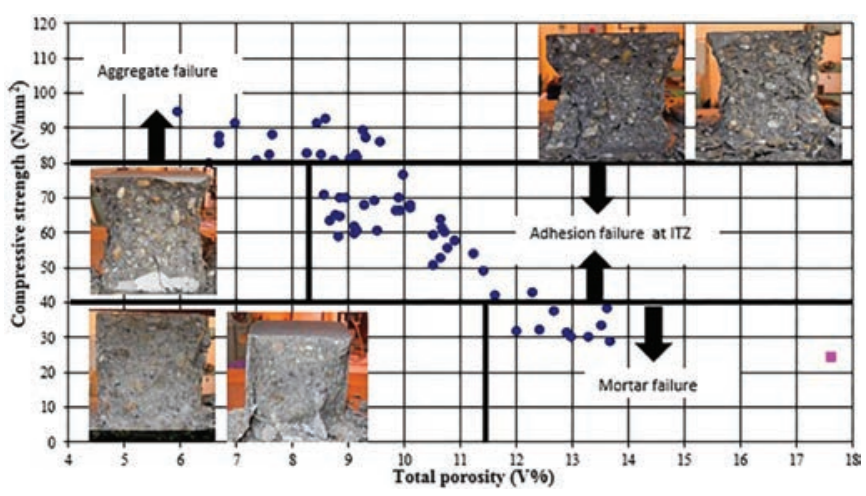

Fig. 1. Concrete compressive strength vs. total porosity [14] 1. ábra Beton nyomószilárdság és teljes porozitás kapcsolata [14] 


\section{Experimental details}

\subsection{Materials}

CEM I $42.5 \mathrm{~N}$ was used in the first concrete mixture category (denoted as $\mathrm{H}$-type) for HSC in the present experiments. For the other types of concrete mixtures, CEM I $52.5 \mathrm{~N}$ and CEM II $42.5 \mathrm{~A}-\mathrm{S}$ was implemented $50-50 \%$ as the main bindery materials in UHSC (denoted as U-type). Metakaolin and silica fume were added as SCM to the mixtures. Fine and coarse aggregates were collected from local sources in Budapest, Hungary. For the $\mathrm{H}$ - type, a fixed proportion of particle size distribution was applied as $40 \%$ sand $(0-4 \mathrm{~mm}), 30 \%$ small gravel $(4-8 \mathrm{~mm})$, and $30 \%$ medium gravel $(8-16 \mathrm{~mm})$, respectively. Gravel was extracted from Danube River which is used as aggregate. Maximum size of aggregate was $D_{\max }=$ $16 \mathrm{~mm}$. U-type particle size distribution was applied as 30\% very fine sand $(0.2-0.6 \mathrm{~mm}), 10 \%$ fine sand $(0.4-1 \mathrm{~mm}), 35 \%$ medium sand (1-2.5 $\mathrm{mm})$ and $25 \%$ coarse sand $(2-5 \mathrm{~mm})$. Natural quartz sand was used as aggregate with maximum size of aggregate $\mathrm{D}_{\max }=2.36 \mathrm{~mm}$. For more information, Fig. 2 presents the particle size distribution curves of aggregates for each H-type concrete. BASF Glenium 51 was applied as superplasticizer (SP) to control water content and to take into account the required workability and performance in fresh stage.

\subsection{Mixture trials}

All concrete mixture trials were performed in the laboratory. According to Table 1, main variable parameters of the first type of mixture were the amount of water and cement, keeping in mind that a constant water to cement ratio is assured. A range of $0-20 \%$ of silica fume SCM was implemented in the concrete mix. High range water reducing admixture was used to compensate the low amount of water and assure the adequate rheological properties.

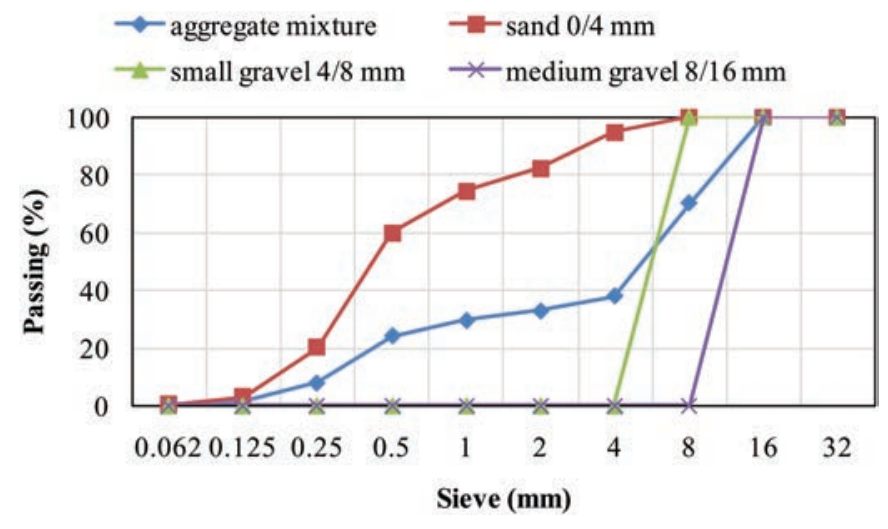

Fig. 2. Particle size distribution of H-mixtures aggregates

2. ábra Szemcseméret-eloszlás; H-jelü keverékek adalékanyagai

\subsection{Experiments}

Standard cube specimens were tested under a constant loading rate of $11.25 \mathrm{kN} / \mathrm{s}$ using a universal closed-loop hydraulic testing machine during the compressive strength testing according to EN 12390-3 European Standard [15]. Tests were performed at 1, 3, 7 and 28 days respectively for H-type mixture. Regarding U-type mixture, compressive strength was tested at the age of 7 and 28 days. At each age, three specimens were tested in compression.

\section{Results}

Fig. 3 illustrates the results of compressive strength of HSC mixtures at the age of $1,3,7$ and 28 days. It can be seen the variation of compressive strength depends on the dosage of

\begin{tabular}{lcccccccccccc} 
Mixtures & H0-1 & H0-2 & H10-1 & H10-2 & H20-1 & H20-2 & H0-C1 & H0-C2 & H10-C1 & H10-C2 & H20-C1 & H20-C2 \\
Cement & 380 & 380 & 345 & 345 & 362 & 362 & 440 & 440 & 400 & 400 & 419 & 419 \\
\hline $\begin{array}{l}\text { Silica } \\
\text { fume }\end{array}$ & 0 & 0 & 34.5 & 34.5 & 18.1 & 18.1 & 0 & 0 & 40 & 40 & 20.95 & 20.95 \\
\hline Water & 113.2 & 134 & 113.1 & 133.8 & 113.3 & 134 & 128.9 & 151.8 & 128.9 & 151.8 & 128.9 & 151.8 \\
\hline $\mathbf{0 - 4}$ & 801 & 784 & 796 & 780 & 798 & 782 & 761 & 742 & 755 & 736 & 758 & 739 \\
\hline $\mathbf{4 - 8}$ & 601 & 588 & 597 & 585 & 599 & 586 & 571 & 556 & 566 & 552 & 568 & 554 \\
\hline $\mathbf{8 - 1 6}$ & 601 & 588 & 597 & 585 & 599 & 586 & 571 & 556 & 566 & 552 & 568 & 554
\end{tabular}

Table 1. H-type concrete mixtures proportions in $\mathrm{kg} / \mathrm{m}^{3}$

1. táblázat $H$-jelü betonkeverékek összetétele $\mathrm{kg} / \mathrm{m}^{3}$

\begin{tabular}{lcccccccc}
\multicolumn{1}{r}{ Mixtures } & U1 & U2 & U3 & U4 & U5 & U6 & U7 \\
Cement & 600 & 600 & 600 & 600 & 660 & 660 & 600 \\
\hline Silica fume & 48 & 0 & 42 & 48 & 52.8 & 52.8 & 48 \\
\hline Metakaolin & 102 & 120 & 78 & 102 & 112.02 & 112.02 & 102 \\
\hline FL Quartz & 0 & 200 & 200 & 300 & 300 & 240 & 240 \\
\hline Water & 187 & 180 & 174 & 180 & 198 & 198 & 180 \\
\hline $\mathbf{0 . 2 - 0 . 6}$ & 330 & 377 & 380 & 335 & 299 & 317 & 352 \\
\hline $\mathbf{0 . 4 - 1}$ & 110 & 126 & 127 & 112 & 100 & 106 & 117 \\
\hline $\mathbf{1 - 2 . 5}$ & 275 & 314 & 317 & 391 & 348 & 370 & 411 \\
\hline $\mathbf{2 - 5}$ & 385 & 439 & 444 & 280 & 249 & 264 & 293
\end{tabular}

Table 2. U-type concrete mixtures proportions in $\mathrm{kg} / \mathrm{m}^{3}$

2. táblázat U-jelü betonkeverékek összetétele $\mathrm{kg} / \mathrm{m}^{3}$ 


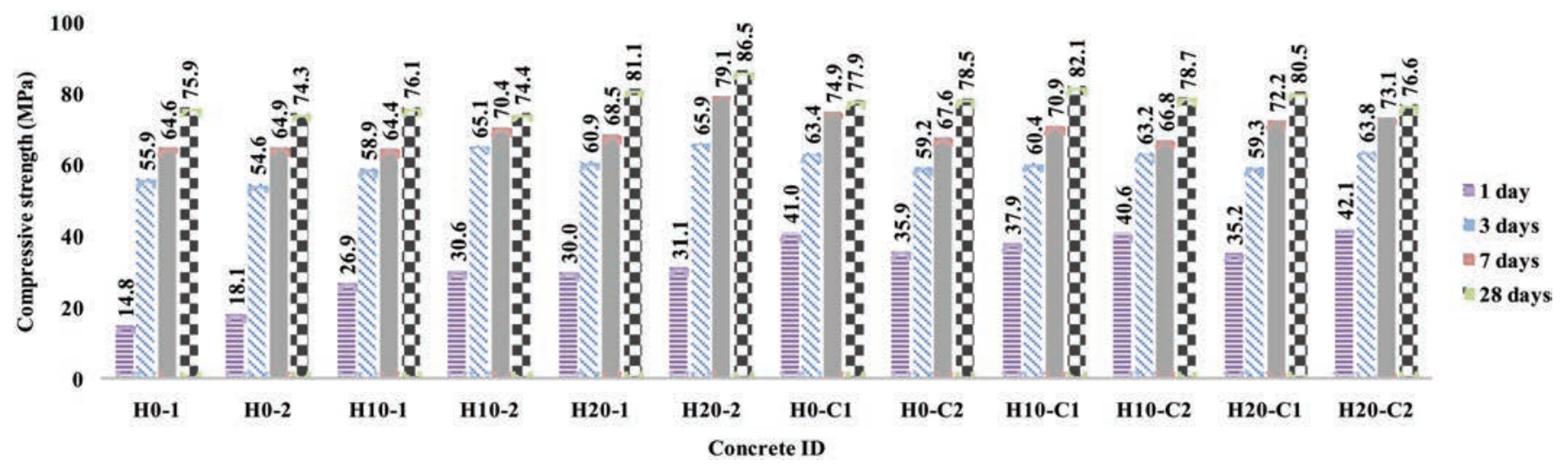

Fig. 3. Mean compressive strength of H-type concrete specimens at the age of 1, 3, 7 and 28 days 3. ábra H-jelü betonkeverékek átlagos nyomószilárdsága 1, 3, 7 és 28 napos korban

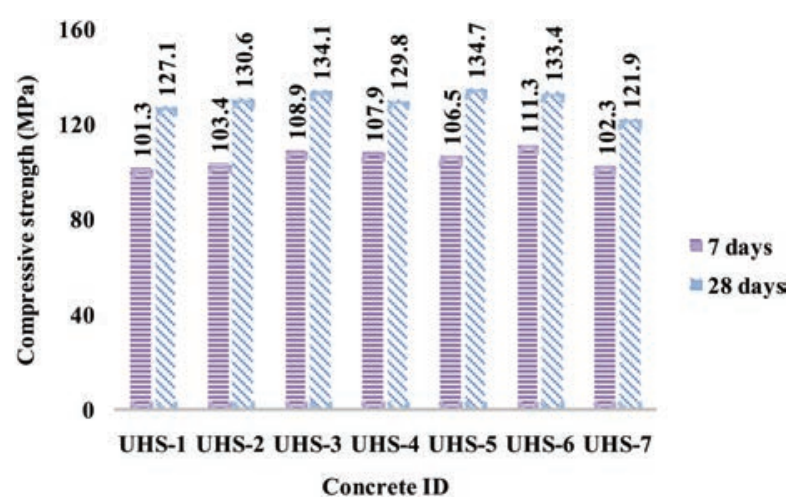

Fig. 4. Mean compressive strength of U-type concrete specimens at the age of 7 and 28 days 4. ábra U-jelü betonkeverékek átlagos nyomószilárdsága 7 és 28 napos korban

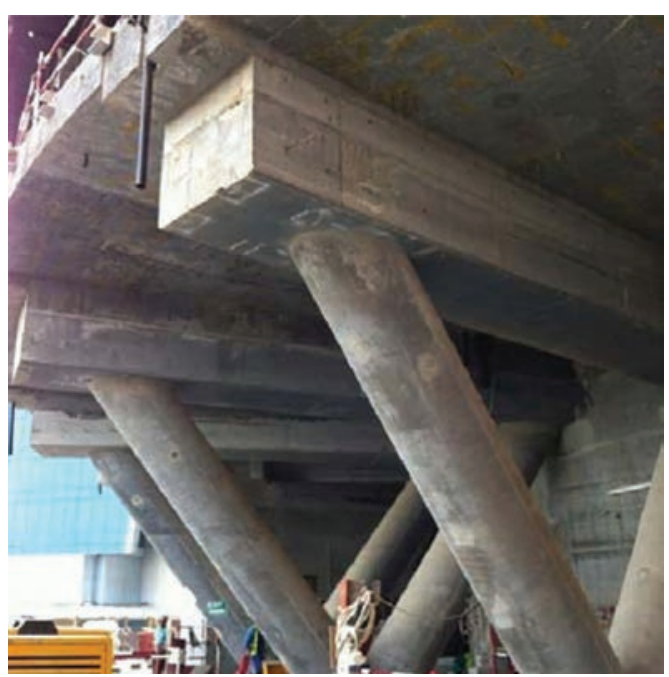

Fig. 5. V-shaped columns of Regent Pearl Hotel located in U.A.E. [16] 5. ábra V-alakú pillérek a Regent Pearl Hotel tartószerkezetében [16]

SF applied. The lowest value at the early ages ( 1 and 3 days) corresponds to $\mathrm{H} 0-1\left(14.75 \mathrm{~N} / \mathrm{mm}^{2}\right)$ for $0 \mathrm{~m} \%$ of cement substitution of SCM. However, H20-C2 showed the highest value of compressive strength $\left(42.05 \mathrm{~N} / \mathrm{mm}^{2}\right)$ for $20 \mathrm{~m} \%$ of cement substitution by silica fume. This development of compressive strength showed approximately similar values for $\mathrm{H} 0-\mathrm{C} 1, \mathrm{H} 10-\mathrm{C} 1$ and $\mathrm{H} 10-\mathrm{C} 2$. Hence $10 \%$ of cement substitution by silica fume would be the limited value to get a similar compressive strength at early ages in comparison with $20 \%$ mass of cement substitution. At the age of 28 days, H20-2

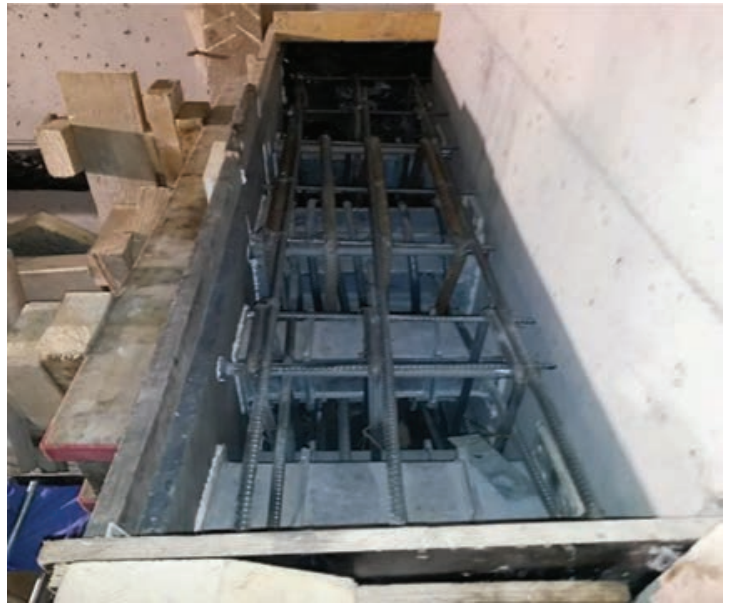

Fig. 6.a. Formwork section close up 6.a ábra Zsaluzat kialakítása

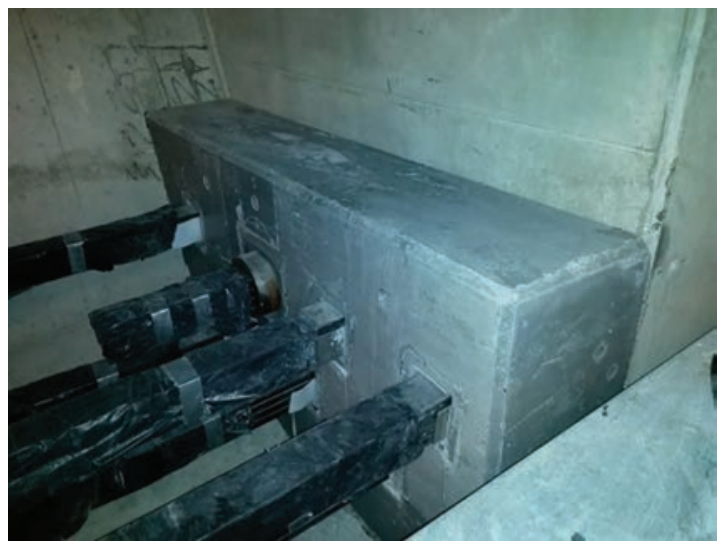

Fig. 6.b. Final concrete section 6.b ábra A végleges megerősités

showed the highest value of compressive strength. However, H10-C2, at $10 \%$ of cement mass replacement, showed approximately a close value of $82 \mathrm{~N} / \mathrm{mm}^{2}$.

UHSC U-type mixtures compressive strength results are presented in Fig. 4. At a total content of binders $\left(824.82 \mathrm{~kg} / \mathrm{m}^{3}\right)$, U5 showed the highest compressive strength reaching $134.7 \mathrm{~N} /$ $\mathrm{mm}^{2}$ at the age of 28 days. This strength was obtained by means of $8 \% \mathrm{SF}$ and $17 \% \mathrm{MK}$ mass replacement of cement. Also all U-type mixtures exceeded the compressive strength of $100 \mathrm{~N} /$ $\mathrm{mm}^{2}$ at the age of 7 days. 


\section{Site applications}

HSC and UHSC mixtures are used in several occasions especially in high rise buildings, long span bridges and enhancement or repair cases. According to Fig. 5, V-shaped columns were placed for a high rise hotel located in Abu-Dhabi where C75 concrete was used [16]. Moreover, some applications require higher compressive strength. For instance, Fig. 6 show a case reported in Budapest, Hungary where critical cracks were visualized on diaphragm walls of a bridge. Enhancement was required to provide the minimum mechanical and durability properties needed for an adequate service life. C100 concrete was used for the repair.

It should be noted that the utilization of HSC and UHSC in these applications has solved many difficulties such as vibrating and filling concrete into the formwork. Also manpower needed to fill formworks has been decreased in comparison with conventional concrete application [17].

\section{Conclusions}

Optimized HSC and UHSC were obtained based on trial batches and alterations of SCM incorporated in the mixtures. The following conclusions can be drawn:

- Mixtures incorporating SCM showed an increase in the compressive strength with respect to mixture that includes only cement as a binding material.

- High early compressive strength can be reasonably reached by applying HSC and UHSC technology.

- The SCM content in concrete mixtures has limited range for appropriate performance. In case of silica fume, $8-10 \%$ mass replacement of cement would be the maximum amount applied. However, in case of metakaolin, 17-20\% mass replacement of cement would be the maximum limited amount.

- Application of HSC and UHSC solves filling difficulties and helps to produce more attractive surfaces in terms of aesthetic appearances.

- More investigation is essentially required in terms of durability to understand the behaviour of such concretes for longer service life structures.

\section{Acknowledgement}

Authors are grateful to the Hungarian Scientific Research Fund (OTKA) for the financial support of the OTKA K 109233 research project.

References

[1] Schmidt, M. - Fehling, E. (2004): Ultra-High-Performance Concrete: Research, Development and Application in Europe,Proceedings for International Symposium on Ultra-High Performance Concrete, Kassel, Germany, p. 32.

[2] ACI Committee 363R (1997): State-of-the-art report on high-strength concrete. American Concrete Institute

[3] Borosnyói, A. (2015): Development of compressive strength of HPC with the use of supplementary cementing material (SCM) combination, Épitöanyag - Journal of Silicate Based and Composite Materials, Vol. 67, No. 3, pp. 110-115. http://dx.doi.org/10.14382/epitoanyag-jsbcm.2015.18
[4] Kara, P. (2015): Performance of lamp glass waste powder (LGWP) as supplementary cementitious material (SCM) - viscosity and electrical conductivity, Épitöanyag - Journal of Silicate Based and Composite Materials, Vol. 67, No. 1, pp. 12-18.

http://dx.doi.org/10.14382/epitoanyag-jsbcm.2015.3

[5] Kara, P. - Borosnyói, A. - Fenyvesi, O. (2014): Performance of waste glass powder (WGP) supplementary cementitious material (SCM) - Drying shrinkage and early age shrinkage cracking, Épitöanyag - Journal of Silicate Based and Composite Materials, Vol. 66, No. 1, pp. 18-22. http://dx.doi.org/10.14382/epitoanyag-jsbcm.2014.4

[6] Borosnyói, A. - Kara, P. - Mlinárik, L. - Kase, K. (2013): Performance of waste glass powder (WGP) supplementary cementitious material (SCM) - Workability and compressive strength Épitöanyag, Vol. 65, No. 3, pp. 90-94. http://dx.doi.org/10.14382/epitoanyag-jsbcm.2013.17

[7] Cheyrezy, M. - Maret, V. - Frouin, L. (1995): Microstrctural analysis of RPC (reactive powder concrete). Cement and Concrete Research, Vol. 25, No. 7, pp. 1491-1500. http://dx.doi.org/10.1016/0008-8846(95)00143-Z

[8] Nehme, S. G. (2015): Influence of supplementary cementing materials on conventional and self-compacting concretes - Part. 1. Literature review, Épitöanyag - Journal of Silicate Based and Composite Materials, Vol. 67. No.1, pp. 28-33. (in Hungarian)

http://dx.doi.org/10.14382/epitoanyag-jsbcm.2015.6

[9] Nehme S. G. (2015): Influence of supplementary cementing materials on conventional and self-compacting concretes - Part. 2. Laboratory tests, Épitöanyag - Journal of Silicate Based and Composite Materials, Vol. 67. No.2, pp. 71-78. (in Hungarian)

http://dx.doi.org/10.14382/epitoanyag-jsbcm.2015.12

[10] El Mir, A. - Nehme, S. G. (2015): Porosity of Self-compacting Concrete, Procedia Engineering, Vol.123, pp. 145-152.

http://dx.doi.org/10.1016/j.proeng.2015.10.071

[11] Pekár, Gy. (2013): Simple basic model for concrete and its application. Part 1. Content indicators of concrete mixtures and mixing plant observations, Építöanyag, Vol. 65, No. 2, pp. 52-60. (in Hungarian) http://dx.doi.org/10.14382/epitoanyag-jsbcm.2013.12

[12] Pekár, Gy. (2013): Simple basic model for concrete and its application. Part 2. Factors that influence compressive strength and drying shrinkage, Épitöanyag, Vol. 65, No. 3, pp. 76-84. (in Hungarian) http://dx.doi.org/10.14382/epitoanyag-jsbcm.2013.15

[13] Pekár, Gy. (2013): Simple basic model for concrete and its application. Part 3. Factors affecting consistency, material balance equations and mix design, Épitöanyag, Vol. 65, No. 4, pp. 118-126. (in Hungarian) http://dx.doi.org/10.14382/epitoanyag-jsbcm.2013.22

[14] Nehme, S. G. (2004): The porosity of concrete, PhD thesis, 58 p. (in Hungarian)

[15] CEN (2009): Testing hardened concrete. Compressive strength of test specimens. EN 12390-3:2009 European Standard

[16] http://www.skyscrapercity.com/showthread.php?t=1785186\&page=2

[17] El Mir, A. (2012): Training Report of the Regent Emirates Pearl Hotel, Unpublished manuscript, Arabian Construction Company.

Ref.:

El Mir, Abdulkader - Nehme, Salem Georges - Nehme, Kinga: In situ application of high and ultra high strength concrete Építőanyag - Journal of Silicate Based and Composite Materials, Vol. 68, No. 1 (2016), 20-23. p. http://dx.doi.org/10.14382/epitoanyag-jsbcm.2016.4

Nagyszilárdságú és ultra-nagyszilárdságú betonok gyakorlati alkalmazása

Nagy szilárdságú (HSC) és ultra nagy szilárdságú (UHSC) betonkeverékek laboratóriumi vizsgálatain keresztül a szerzők igazolták, hogy 80-140 MPa nyomószilárdság tartományban a szilikapor kiegészítô anyag optimális mennyisége 8\%, a metakaolin kiegészitố anyag optimális mennyisége 17\%, a cement tömegére vonatkoztatva.

Kulcsszavak: nyomószilárdság, nagy szilárdságú beton, optimalizálás, ultra nagy szilárdságú beton. 